\title{
KARAKTERISTIK KLINIS PENYAKIT TUBERKULOSIS PARU PADA ANAK
}

\author{
Yogi Arvendo Pratama \\ Fakultas Kedoktern, Universitas Lampung, Jl. Prof. DR. Ir. Sumatri Brojonegoro No.1, Gedong Meneng, \\ Kec. Rajabasa, Kota Bandar Lampung, Lampung, Indonesia 35145 \\ yogi.arvendo@gmail.com (+6282373730133)
}

\begin{abstract}
ABSTRAK
Tuberkulosis merupakan infeksi penyebab mortalitas dan morbiditas utama di negara-negara berkembang. Diperkirakan penyakit tuberkulosis paru menginfeksi sebanyak satu juta anak di dunia dan menyebabkan 210.000 kematian setiap tahunnya. Kejadian tuberkulosis paru pada anak disebabkan oleh Mycobacterium tuberkulosis. Tujuan dari penulisan ini yaitu untuk memahami karakteristik klinis penyakit tuberkulosis paru pada anak termasuk gejala klinis dan pemeriksaan yang digunakan untuk mengonfirmasi penyakit tersebut. Metode penelitian yang digunakan adalah metode literature review dari 22 artikel yang berasal dari PubMed, Medscape, Google Scholar, dan WHO, dan hanya 15 artikel yang digunakan dari tahun 1990 hingga tahun 2020. Hasil yang didapatkan dari penelitian ini yaitu diketahui bahwa gejala yang muncul dari tuberkulosis paru pada anak tidak spesifik gejala bisa berupa demam, batuk, berat badan tidak mengalami peningkatan atau bahkan turun dalam 2 bulan terakhir, keringat pada malam hari, lesu, dan anak terlihat kurang aktif bermain. Penyakit ini dapat dikonfirmasi dengan menggunakan pemeriksaan uji tuberkulin, foto toraks, kultur bakteri, dan pemeriksaan mikroskopis bakteri.
\end{abstract}

Kata kunci: karakteristik klinis; pemeriksaan diagnostik; tuberkulosis pada anak

\section{CLINICAL CHARACTERISTICS OF PULMONARY TUBERCULOSIS IN CHILDREN}

\begin{abstract}
Tuberculosis is the leading cause of mortality and morbidity infection in developing countries. It is estimated that pulmonary tuberculosis infects as many as one million children worldwide and causes 210,000 deaths each year. The incidence of pulmonary tuberculosis in children is caused by Mycobacterium tuberculosis. The purpose of this paper is to understand the clinical characteristics of pulmonary tuberculosis in children including clinical symptoms and examinations used to confirm the disease. The research method used is the literature review method of 22 articles from PubMed, Medscape, Google Scholar, and WHO, and only 15 articles were used from 1990 to 2020. The results obtained from this study are known that the symptoms that arise from pulmonary tuberculosis in children are not specific symptoms can be fever, cough, weight has not increased or even decreased in the last 2 months, sweat at night, lethargy, and children look less active playing. The disease can be confirmed using tuberculin test, thoracic photo, bacterial culture, and microscopic examination of bacteria.
\end{abstract}

Keywords: clinical characteristics; diagnostic examination; tuberculosis in children

\section{PENDAHULUAN}

Tuberkulosis merupakan infeksi penyebab mortalias dan morbiditas utama di negara-negara berkembang.
Wilayah Asia memiliki jumlah penderita tuberkulosis terbesar di dunia, dengan sepuluh kali lipat laporan kasus pada anak-anak lebih besar 
dibandingkan Eropa pada tahun 2012. Diperkirakan sekitar 1 juta anak di India setiap tahun beresiko terinfeksi karena berkontak dengan orang dewasa yang memiliki BTA-positif. Di Thailand, penelitian surveilans di empat provinsi dan satu rumah sakit, menunjukan bahwa hanya 279 (2\%) dari 14.487 total kasus tuberkulosis terjadi pada anakanak yang dilaporkan, ini mungkin terjadi karena sulitnya dalam menegakkan diagnosis penyakit tuberkuosis pada anak (Seddon \& Shingadia, 2014).

Di Indonesia proporsi kasus tuberkulosis pada anak di tahun 2010 berjumlah 9,4\%, tahun 2011 berjumlah, $8,5 \%$, tahun 2012 berjumlah 8,2\%, tahun 2013 berjumlah 7,9\%, tahun 2014 berjumlah 7,16\%, dan pada tahun 2015 berjumlah 9\% (Subuh \& Waworuntu, 2016).

Infeksi tuberkulosis menyebar dengan cepat melalui air droplet atau udara yang mengandung Mycobacterium tuberculosis, dengan ukuran partikel 1 sampai $5 \mu \mathrm{m}$ sehingga sangat mudah masuk ke paru-paru lalu menuju alveolus tempat bakteri tersebut bereplikasi. Droplet keluar diudara ketika orang dengan tuberkulosis sedang batuk, bersin, bicara, membuang dahak sembarangan, dan juga ketika melakukan tindakan medis contohnya seperti bronkoskopi. Droplet nuklei mengandung dua sampai tiga $M$. tuberculosis, diruangan tertutup dan lembab bakteri tersebut dapat bertahan kurang lebih selama satu sampai dua jam (Dunlap et al., 1990).

Anak memiliki risiko yang jauh lebih tinggi untuk terpajan tuberkulosis di wilayah yang angka kejadian tuberkulosisnya cukup besar. Kepadatan populasi juga mempengaruhi risiko anak untuk mengalami tuberkulosis, karena populasi yang padat menyebabkan interaksi yang lebih intens dan berpengaruh terhadap persebaran bakteri Mycobacterium tuberculosis (Martinez et al., 2020).

Usia anak akan mempengaruhi risiko mereka terpajan tuberkulosis, karena anak yang lebih besar berinteraksi dengan lebih banyak orang dewasa dalam kehidupan sehari-hari mereka. Oleh karena itu mereka dapat terpajan pada kasus tuberkulosis infeksius dirumah atau di masyarakat. Anak-anak yang lebih muda, terutama pra-sekolah, berinteraksi lebih sedikit dengan orang dewasa dan ini akan mempengaruhi kemungkinan mereka terpapar pada orang dewasa dengan tuberkulosis yang menular (Donald et al., 2010).

Selain usia anak, bahan bangunan rumah, struktur fisik rumah, dan kebiasaan tidur akan mempengaruhi risiko pajanan. Kepadatan manusia di dalam rumah akan berdampak pada risiko pajanan kasus tuberkulosis. Anak yang tinggal dirumah dengan banyak orang dewasa lebih mungkin untuk bersentuhan dengan kasus yang infeksius. Di beberapa komunitas masyarakat, anak-anak tidur bersama di suatu ruangan dengan orang dewasa di ruangan lain. Sedangkan di komunitas lain keluarga tidur diruangan yang sama (Willis et al., 2012).

Infeksi tuberkulosis terdapat dua jenis, yaitu tuberkulosis aktif dan tuberkulosis laten. Tuberkulosis aktif adalah tuberkulosis yang menimbulkan gejala dan menular, sedangkan tuberkulosis laten dimana penderita tidak menunjukan gejala dan bakteri tersebut bersifat dorman. Tanda-tanda klinis seorang anak terinfeksi tuberkulosis paru tidak spesifik, muncul dengan 
demam, berat badan yang menurun, dan juga adanya infeksi saluran nafas akut yang berulang, sehingga sering kali kesulitan dalam mendiagnosis tuberkulosis paru secara klinis (Subuh \& Waworuntu, 2016).

Syarat untuk menegakkan diagnosis klinis tuberkulosis paru pada anak yaitu dengan ditemukan Mycobacterium tuberculosis dari sputum atau dahak, cairan lambung, sampel biopsi jaringan, dan lain-lain. Tetapi, pemeriksaan tersebut sulit dan jarang dilakukan, kebanyakan diagnosis tuberkulosis paru pada anak didasarkan dari gambaran klinis yang spesifik, gambaran radiologis, dan uji tuberkulin (Putra \& Amelia, 2013). Penelitian ini dibuat dengan metode literature review yang bertujuan untuk mengetahui bagaimana karakteristik klinis tuberkulosis paru pada anak seperti gejala klinis, dan pemeriksaan-pemeriksaan penunjang yang dapat digunakan untuk membantu penegakkan diagnosis penyakit tuberkulosis paru pada anak.

\section{METODE}

Penulisan ini dibuat menggunakan metode literature review. Penulisan ini menggunakan sebanyak 15 jurnal yang berasal dari PubMed, Medscape, Google Scholar, dan WHO dengan kata kunci clinical characteristic, diagnostic examination, dan tuberculosis in children. Kemudian jurnal-jurnal tersebut dievaluasi, dan diinterpretasikan sesuai dengan fokus bahasan tertentu. Tahun terbitan sumber yang digunakan pada penulisan ini adalah dalam rentang tahun 1990 hingga tahun 2020.

\section{HASIL}

Tuberkulosis paru adalah penyakit menular yang ditransmisikan melalui aerosol, penyebabnya yaitu
Mycobacterium tuberculosis yang masuk ke paru-paru dan bereplikasi di alveolus. Secara patologi terjadi peradagan di paru-paru yang ditandai dengan adanya nekrosis granulomatosa. Paparan Mycobacterium tuberculosis jarang menyebabkan gejala yang khas (Martinez et al., 2020).

Tuberkulosis paru pada anak bisa menunjukan tanda-tanda klinis yang tidak spesifik dan khas, sehingga bisa menyebabkan kesalahan diagnosis yang berpengaruh terhadap penatalaksanaan dan dapat menyebabkan perburukan keadaan seiring dengan berjalannya waktu. Beberapa anak dengan tuberkulosis paru aktif bisa saja asimtomatik, dimana keadaan ini sulit dibedakan dengan tuberkulosis laten (Dunlap et al., 1990).

Gejala utama tuberkulosis paru pada anak meliputi kelelahan, anoreksia, keringat pada malam hari, lemas, penurunan berat badan dan anak terlihat kurang aktif. Ketika infeksi bakteri semakin berkembang, anak mengalami keluhan nyeri dada, batuk, dan hemoptisis (jarang terjadi). Tanda dan gejala lain termasuk demam yang umumnya tidak tinggi (berlangsung kurang lebih selama 15 hari, dan sering muncul dimalam hari), limfadenopati, dan hepatosplenomegali. Batuk yang persisten adalah gejala utama dari tuberkulosis paru pada anak yang umum ditemukan (Carvalho et al., 2018).

Sebagian anak yang terinfeksi Mycobacterium tuberculosis umumnya tidak menunjukan ciri serta indikasi yang berarti. Gejala primer yang paling umum pada anak-anak adalah batuk $\geq 2$ minggu dan demam $\geq 2$ minggu. Dalam beberapa situasi anak-anak bisa mengalami flu-like syndrome yang pulih dalam waktu seminggu. Pada bayi 
karena saluran nafas berukuran kecil dapat menunjukan manifestasi klinis seperti batuk nonproduktif, dispnea ringan, dan berat badan tidak mengalami peningkatan atau bahkan turun dalam 2 bulan terakhir (Velayati, 2016).

Gambaran klinis yang ditunjukan pada pemeriksaan radiologis yaitu pembengkakan kelenjar hilus ataupun paratrakeal dengan atau tanpa infiltrat, konsolidasi segmental/lobar, efusi pleura, milier, atelectasis, kavitas, kalsifikasi dengan infiltrate, dan tuberkuloma. Pada pemeriksaan histopatologi akan menunjukan terjadinya nekrosis perkijuan dibagian tengah granuloma dan terlihat adanya sel datia langhans dan atau Mycobacterium tuberculosis (Subuh \& Waworuntu, 2016).

Tuberkulosis pada anak dapat dikonfirmasi dengan menggunakan pemeriksaan baktiologis. Gold-standard untuk diagnosis tuberkulosis adalah kultur bakteri dengan ditemukannya Mycobacterium tuberculosis sekitar 10 hingga 100 koloni per mililiter (CFU/mL) di media kultur padat ataupun cair. Sampel bisa berasal dari sputum, bilas lambung, caian cerebrospinal, cairan pleura, ataupun biopsi jaringan. Selain kultur bakteri, dapat dilakukan uji tuberkulin. Uji tuberkulin bermanfaan untuk menegakkan diagnosis tuberkulosis pada anak, khususnya jika riwayat kontak dengan pasien tuberkulosis tidak jelas (Thomas, 2017).

\section{PEMBAHASAN}

Penyakit tuberkulosis paru pada anak diakibatkan infeksi Mycobacterium tuberculosis yang ditransmisikan melalui aerosol. Sebagian besar orang dewasa yang terinfeksi tuberkulosis dapat menyebarkan Mycobacterium tuberkulosis ke anak-anak di sekitar mereka. Diperkirakan penyakit tuberkulosis paru menginfeksi sebanyak satu juta anak di dunia dan menyebabkan 210.000 kematian setiap tahunnya. Jumlah terbesar kasus anak dengan tuberkulosis yaitu terdapat di negara India, Bangladesh, dan Indonesia (Lamb \& Starke, 2017).

Beberapa penelitian mengatakan bahwa kepadatan populasi berpengaruh terhadap risiko anak untuk mengalami tuberkulosis. Populasi padat menyebabkan interaksi yang intens dan durasi berkontak dengan penderita tuberkulosis semakin tinggi sehingga berpengaruh terhadan persebaran Mycobacterium tuberkulosis (Martinez et al., 2020; Donald et al., 2010). Hasil penelitian Hajarsyah dkk menyatakan bahwa, faktor risiko yang paling berpengaruh terhadap kejadian tuberkulosis pada anak-anak selain durasi kontak dengan penderita adalah status gizi, lalu diikuti status imunisasi, jumlah orang yang tinggal dalam satu rumah, dan kebiasaan tidur dalam satu ranjang (Hajarsyah et al., 2018).

Menurut Kementrian Kesehatan RI tahun 2016, alur penegakkan diagnosis tuberkulosis pada anak didasarkan 4 hal yaitu: 1). Tanda-tanda klinis yang spesifik TB pada anak 2).Konfirmasi Bakteriologis TB 3). Adanya tanda infeksi TB, terdapat hasil uji tuberkulin atau adanya riwayat berkontak dengan kasus TB aktif 4). Hasil pemeriksaan radiologi menunjukan gambaran yang spesifik TB (Subuh \& Waworuntu, 2016).

Untuk membantu penegakkan diagnosis tuberkulosis pada anak, selain melihat dari gejala klinis, juga dilakukan pemeriksaan yang paling mudah yaitu 
Tuberculin Skin Test. Pemeriksaan ini dilakukan dengan menyuntikan purified protein derivate sebanyak $0,1 \mathrm{ml}$ intradermal lalu mengukur diameter indurasi (tonjolan), hasil pengukuran bermakna positif jika diameter indurasi $\geq 5 \mathrm{~mm}$. Hasil pemeriksaan tuberkulin bisa terjadi negatif palsu pada anakanak dengan penyakit sistem imun, dan positif palsu yang bisa disebabkan oleh infeksi mikrobakteri nontuberkulosis atau pada anak-anak yang baru diberi vaksin BCG (Dunn et al., 2016).

Menurut World Health Organization (WHO), gold-standard untuk menegakkan diagnosis penyalit tuberkulosis paru adalah ditemukannya Mycobacterium tuberkulosis pada kultur bakteri (WHO, 2014). Namun, untuk melakukan kultur bakteri membutuhkan infrastruktur laboratorium yang memadai dan juga memakan waktu yang cukup lama. Oleh karena itu, meskipun sensitivitasnya $\leq 50 \%$ untuk menemukan basil tahan asam (BTA) dalam sampel sputum, pemeriksaan mikroskopis bakteri merupakan metode cepat yang paling banyak digunakan untuk mendiagnosis tuberkulosis paru, dan seringkali menjadi satu-satunya tes diagnostik yang tersedia (Achkar et al., 2011).

\section{SIMPULAN}

Penyakit tuberkulosis paru pada anak diakibatkan infeksi Mycobacterium tuberculosis. Berdasarkan hasil literature review diketahui bahwa karakteristik klinis pada penyakit tuberkulosis paru pada anak yaitu gejala yang timbul bisa berupa gejala ringan dan tidak spesifik. Gejalanya berupa deman, batuk, berat badan tidak mengalami peningkatan atau bahkan turun dalam 2 bulan terakhir, keringat pada malam hari, lesu, dan anak kurang aktif bermain. Metode yang digunakan untuk mengonfirmasi kasus tuberkulosis paru pada anak adalah dengan melakukan kultur bakteri dengan ditemukannya Mycobacterium tuberkulosis, tetap metode ini memakan waktu, sehingga pemeriksaan mikroskopis merupakan pemeriksaan penunjang pilihan yang cepat dan paling banyak digunakan untuk mengkonfirmasi kasus tuberkulosis.

\section{DAFTAR PUSTAKA}

Achkar, J. M., Lawn, S. D., Yunus, M., Wright, C. A., \& Kasprowicz, V. O. (2011). Adjunctive Tests for Diagnosis of Tuberculosis : Serology, ELISPOT for SiteSpecific Lymphocytes, Urinary Lipoarabinomannan, String Test, and Fine Needle Aspiration. The Journal Of Infectious Diseases, 204.https://doi.org/10.1093/infdis/ jir450

Carvalho, A. C. C., Cardoso, C. A. A., Martire, T. M., Migliori, G. B., \& Sant'Anna, C. C. (2018). Epidemiological aspects, clinical manifestations, and prevention of pediatric tuberculosis from the perspective of the End TB Strategy. 44(2), 134-144. http://dx.doi.org/10.1590/S180637562017000000461 REVIEW

Donald, P. R., Marais, B. J., \& Barry, C. E. (2010). Age and the epidemiology and pathogenesis of tuberculosis. 375, 1852-1854. https://doi.org/10.1016/S01406736(10)60580-6

Dunlap, N. E., Bass, J., Fujiwara, P., \& Salfinger, M. (1990). Diagnostic standards and classification of tuberculosis. American Thoracic Society Diagnostic, 142(3), 725735.https://doi.org/10.1164/ajrcc $\underline{\mathrm{m} .161 .4 .16141}$ 
Dunn, J. J., Starke, J. R., \& Revell, P. A. (2016). Laboratory Diagnosis of Mycobacterium tuberculosis Infection and Disease in Children. American Society For Microbiology, 54(6), 1434-1441. https://doi.org/10.1128/JCM.0304 3-15.Editor

Hajarsyah, N., Daulay, R. M., Ramayani, O. R., Dalimunthe, W., Daulay, R. S., \& Meirina, F. (2018). positive adults in the household. 58(2), 66-70.

Lamb, G. S., \& Starke, J. R. (2017). Tuberculosis in Infants and Children. American Society For Microbiology, 1-27. 10.1128/microbiolspec.TNMI70037-2016.

Martinez, L., Cords, O., Horsburgh, C. R., Andrews, J. R., AcunaVillaorduna, C., Desai Ahuja, S., Altet, N., Augusto, O., Baliashvili, D., Basu, S., Becerra, M., Bonnet, M., Henry Boom, W., Borgdorff, M., Boulahbal, F., Carvalho, A. C. C., Cayla, J. A., Chakhaia, T., Chan, P. C., Zhu, L. (2020). The risk of tuberculosis in children after close exposure: a systematic review and individualparticipant meta-analysis. The Lancet, 395(10228), 973-984. $\underline{10.1016 / \mathrm{s} 0140-6736(20) 30166-5}$

World Health Organization (2014). Guidance for National Tuberculosis Programmes on the Management of Tuberculosis in Children.

Putra, I. A., \& Amelia. (2013). Profil
Tuberkulosis Pada Anak di Instalasi Rawat Jalan RSUD Raden Mattaher Jambi. Jambi Medical Journal, 1, 51-60. https://doi.org/10.22437/jmj.v1i1. $\underline{2689}$

Seddon, J. A., \& Shingadia, D. (2014). Epidemiology and disease burden of tuberculosis in children: A global perspective. Infection and Drug Resistance, 7, 153-165. https://doi.org/10.2147/IDR.S450 90

Subuh, M., \& Waworuntu, W. (2016). Petunjuk Teknis Manajemen dan Tatalaksana TB Anak. Kementrian Kesehatan Republik Indonesia. Www.Ijjkesehatan.kemenkes.go.id [diakses tanggal 3 Maret 2021]

Thomas, T. A. (2017). Tuberculosis in Children. Pediatric Clinics of NA, 64(4), 893-909. https://doi.org/10.1016/j.pcl.2017. 03.010

Velayati, A. A. (2016). Tuberculosis in children. International Journal of Mycobacteriology, 1-2. https://doi.org/10.1016/j.ijmyco.2 016.10 .038

Willis, M. D., Winston, C. A., Heilig, C. M., \& Cain, K. P. (2012). Seasonality of Tuberculosis in the United States , 1993 - 2008. Clinical Infectious Disease: An Official Publication of the Infectious Disease Society of America, 54(11), 1553-1560. https://doi.org/10.1093/cid/cis235. Seasonality 